\title{
37. MIDDLE EOCENE TO EARLY PLIOCENE BOLBOFORMA (ALGAE?) FROM THE KERGUELEN PLATEAU, SOUTHERN INDIAN OCEAN ${ }^{1}$
}

\author{
Andreas Mackensen² and Dorothee Spiegler ${ }^{3}$
}

\begin{abstract}
Bolboforma were recovered from all sites of Ocean Drilling Program (ODP) Leg 120 to the Central Kerguelen Plateau in the southern Indian Ocean. Eight Paleogene taxa, ranging from middle Eocene through early Oligocene, and nine Neogene taxa, ranging from late middle Miocene through earliest Pliocene, were recognized.

A Bolboforma zonation recently proposed for the middle Paleogene of the Leg 114 sites from the southern Atlantic Ocean is applicable to the Leg 120 material from the southern Indian Ocean. The age of zonal boundaries is consistent within a resolution of $\pm 1 \mathrm{~m}$.y. The ranges of some marker species have been extended, causing a redefinition of some late Eocene zonal boundaries. The revised zonal scheme agrees well with the Paleogene occurrence of Bolboforma species from the Leg 113 sites in the eastern Weddell Sea. This and the consistent presence of Bolboforma in Paleogene cores from the Antarctic ODP legs promise that Bolboforma stratigraphy will become a useful tool for the subdivision of sequences across the Eocene/Oligocene boundary from southern high latitudes.

The stratigraphic subdivision of the Miocene and Pliocene based on a Neogene Bolboforma zonation from the Norwegian Sea proved to be difficult and of limited stratigraphic value for the Leg 120 sites.
\end{abstract}

\section{INTRODUCTION}

On Ocean Drilling Program (ODP) Leg 120, we drilled one site on the northern and four sites on the southern Kerguelen Plateau in the southern Indian Ocean: the northern Site 747 (1696 m water depth; $54^{\circ} 48.68^{\prime} \mathrm{S}, 76^{\circ} 47.64^{\prime} \mathrm{E}$ ) and the four southern Sites 748 (1288 m water depth; $58^{\circ} 26.45^{\prime} \mathrm{S}$, $\left.78^{\circ} 58.89^{\prime} \mathrm{E}\right), 749$ ( $1070 \mathrm{~m}$ water depth; $\left.58^{\circ} 43.03^{\prime} \mathrm{S}, 76^{\circ} 24.45^{\prime} \mathrm{E}\right)$, $750\left(2030 \mathrm{~m}\right.$ water depth; $\left.57^{\circ} 35.54^{\prime} \mathrm{S}, 81^{\circ} 14.42^{\prime} \mathrm{E}\right)$, and 751 (1634 m water depth; $57^{\circ} 43.56^{\prime} \mathrm{S}, 7^{\circ} 48.89^{\prime} \mathrm{E}$ ). These sites recovered $60-160-\mathrm{m}$ thick Neogene sections of foraminifer diatom oozes and diatom nannofossil oozes, and 60- and $320-\mathrm{m}$ thick Paleogene sections of foraminifer oozes and diatom nannofossil oozes (Schlich, Wise, et al., 1989). Leg 120 was the last of four ODP legs around Antarctica (113, 114, 119, and 120) that had one main objective in common: the reconstruction of the paleoceanographic and climatic changes that induced the onset of continental East Antarctic glaciation and the buildup of the Antarctic ice shield during the Cenozoic.

A period of particular interest is around the Eocene/ Oligocene boundary, when major changes in benthic foraminifer assemblages (Douglas and Woodruff, 1981; Tjalsma and Lohmann, 1983; Mackensen and Berggren, this volume, among others), a worldwide shift to heavier values in the stable oxygen isotope composition of benthic foraminifers by about 1.5\% (Savin, 1977; Miller et al., 1987), and findings of ice-rafted material as far north as on the Kerguelen Plateau (Schlich, Wise, et al., 1989; Ehrmann, 1991; Zachos et al., this volume; Breza and Wise, this volume) suggest a substantial cooling of bottom-water masses and probably the onset of continental East Antarctic glaciation.

In the Neogene, periods of particular interest are the early middle Miocene, when the formation of a major continental

\footnotetext{
${ }^{1}$ Wise, S. W., Jr., Schlich, R., et al., 1992. Proc. ODP, Sci. Results, 120: College Station, TX (Ocean Drilling Program).

2 Alfred Wegener Institute for Polar and Marine Research, P. O. Box 120161 , D-2850 Bremerhaven, Federal Republic of Germany.

${ }^{3}$ Research Center for Marine Geosciences, GEOMAR, Wischhofstrasse 1-3, D-2300 Kiel 14, Federal Republic of Germany.
}

ice sheet on East Antarctica intensified (Shackleton and Kennett, 1975; Barker, Kennett, et al; 1988; Hambrey et al., 1989), as well as the late Miocene, when major ice shelves in the Weddell and Ross seas and in Prydz Bay probably were built up (Ciesielski et al., 1982; Mercer, 1983; Barrett, 1989; Hambrey et al., 1991).

During these periods of significant changes in Southern Hemisphere paleoceanography, abundant to frequent Bolboforma were deposited in the Leg 120 sediments (Fig. 1). Bolboforma von Daniels and Spiegler is a stratigraphically useful microfossil of uncertain origin similar in shape to the benthic foraminifer genus Lagena; in contrast to benthic foraminifers, however, it generally consists of monocrystalline low-magnesium calcite (von Daniels and Spiegler, 1974). Bolboforma is currently believed to be an algal cyst. Consequently, it is assigned an uncertain position within the Class Chrysophyceae (Tappan, 1980) and is informally grouped into the Family Bolboformaceae (Spiegler, 1987). However, as specimens with an inner encapsulated test have been found (Poag and Karowe, 1986, 1987; Spiegler, 1987), we suggest that, in comparison with other protophytes, the Bolboforma (outer test) seems to represent the vegetative stage and not the cyst stage of the organism (Spiegler, 1987). Generally, Bolboform $a$ are rare in Oligocene sediments and absent in sediments older than the middle Eocene and younger than the early Pliocene.

During Leg 120, different Bolboforma species were found in Paleogene sediments of Holes 748B and 749B, ranging from the upper middle Eocene through the lower Oligocene (Mackensen and Spiegler, 1989). During the last few years, the number of new finds of Bolboforma rapidly increased, but its description from Paleogene samples is still rare. To date, the oldest Bolboforma is reported from the middle Eocene of ODP Legs 113 in the Weddell Sea (Kennett and Kennett, 1990) and 114 in the southern South Atlantic (Spiegler, 1991). Late Eocene Bolboforma spp. were found in the western North Atlantic and the western South Pacific on Deep Sea Drilling Project (DSDP) Legs 95 and 90 (Poag and Karowe, 1986, 1987), respectively, as well as in the Labrador Sea on ODP Leg 105 (Pallant and Kaminski, 1989). 


\section{Hole 748B}

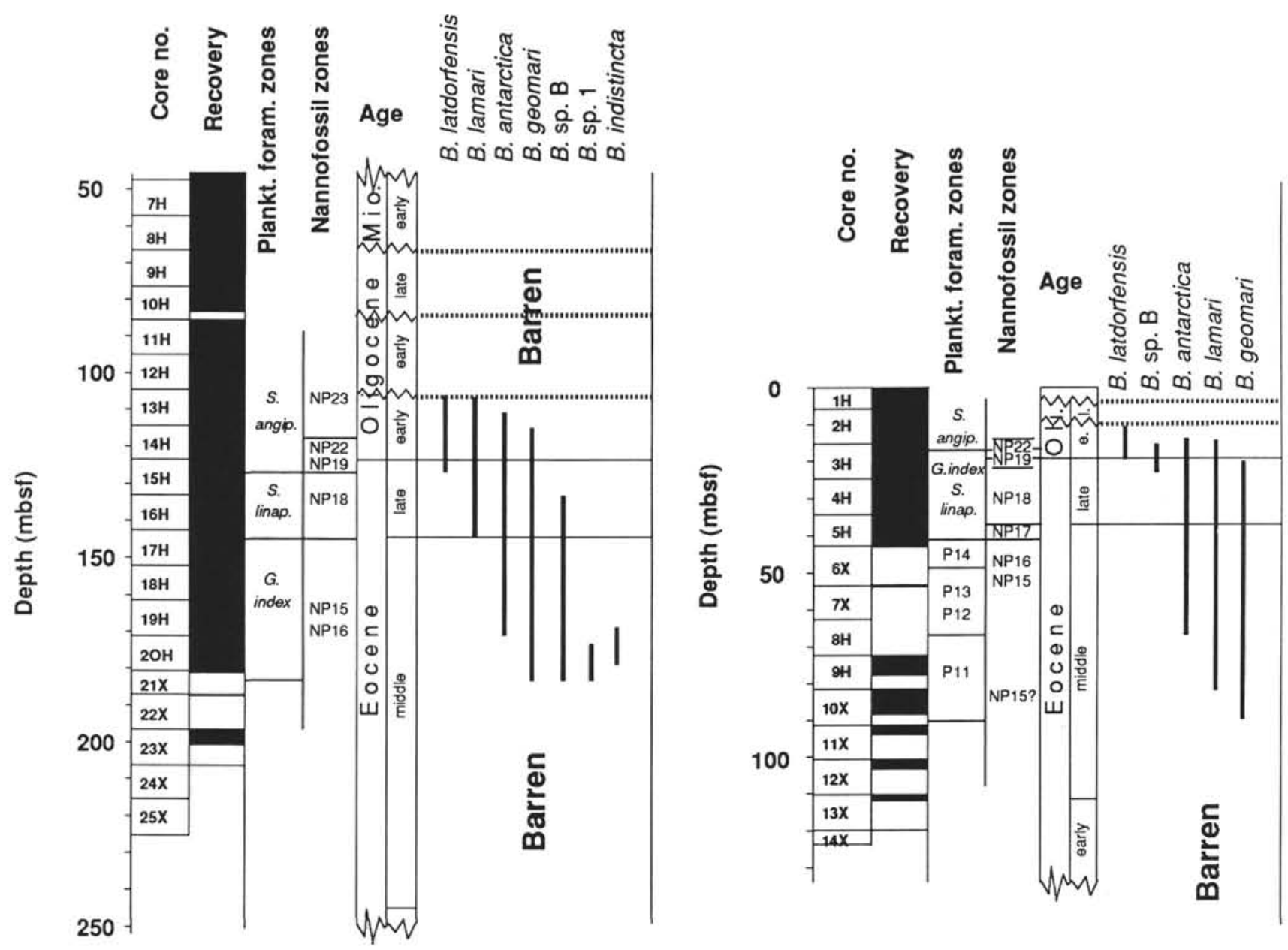

Hole 749B

Figure 1. Ranges of Paleogene Bolboforma taxa plotted vs. core depth. Hiatuses and age estimates are from shipboard stratigraphy (Schlich, Wise, et al., 1989).

In the Neogene sediments of Holes 747B and 751A, Bolboforma were found from the middle Miocene through the lowermost Pliocene. Miocene Bolboforma spp. from northern and southern high latitudes are reported in Rögl and Hochuli (1976), Murray (1979, 1984, 1987), Müller et al. (1984), Echols (1985), McNeil (1988), Poag and Karowe (1986, 1987), Spiegler (1987), Qvale and Spiegler (1989), and Gazdzicki (1989).

\section{MATERIAL AND METHODS}

We investigated 120 samples from lower Miocene through upper Pleistocene sections from Holes 747A, 748B, and 751A, and 88 samples from lower Paleocene through upper Oligocene sections from Holes 747A, 747C, 748B, 748C, 749B, and 750A for the occurrence of Bolboforma. Most of these samples were investigated previously for their benthic foraminifer content; thus, we refer to Mackensen (this volume) and Mackensen and Berggren (this volume) for a detailed listing of all of the samples. The samples were washed through a $63-\mu \mathrm{m}$ mesh sieve and dried in an oven at $60^{\circ} \mathrm{C}$. The residue was dry sieved over a $125-\mu \mathrm{m}$ mesh sieve, and aliquots from this fraction were analyzed. In addition, the $<125-\mu \mathrm{m}$ size fraction was checked, and analyzed, if small Bolboforma were present.
Our taxonomic concept is based on Qvale and Spiegler (1989), Spiegler (1991), and Spiegler and von Daniels (1991). All the species documented and figured in this study (Plates 1 and 2) are briefly described in Spiegler (1991) and Qvale and Spiegler (1989) and fully described and taxonomically discussed in Spiegler and von Daniels (1991). During the review process of this paper, we became aware of a study of Leg 113 Bolboforma by Kennett and Kennett (1990). These authors describe a new Paleogene species, Bolboforma antarctica Kennett and Kennett, which is equivalent to Spiegler's B. eocena from Leg 114 (Spiegler, 1991). Because B. eocena is not completely described in the Leg 114 paper, and the Leg 113 volume will be published first, we adopted $B$. antarctica as the correct name and considered $B$. eocena as a junior synonym. One new middle Eocene species is figured in this paper, but it is kept in open nomenclature because until now it has been found in only two samples of Hole 748B (Plate 2, Figs. 8-9).

The Bolboforma zonations proposed by Spiegler (1991) for the Paleogene and by Qvale and Spiegler (1989) for the Neogene were used in this paper, and were correlated to the planktonic foraminifer and calcareous nannofossil zonations, and radiolarian zonations, respectively (Schlich, Wise, et al., 


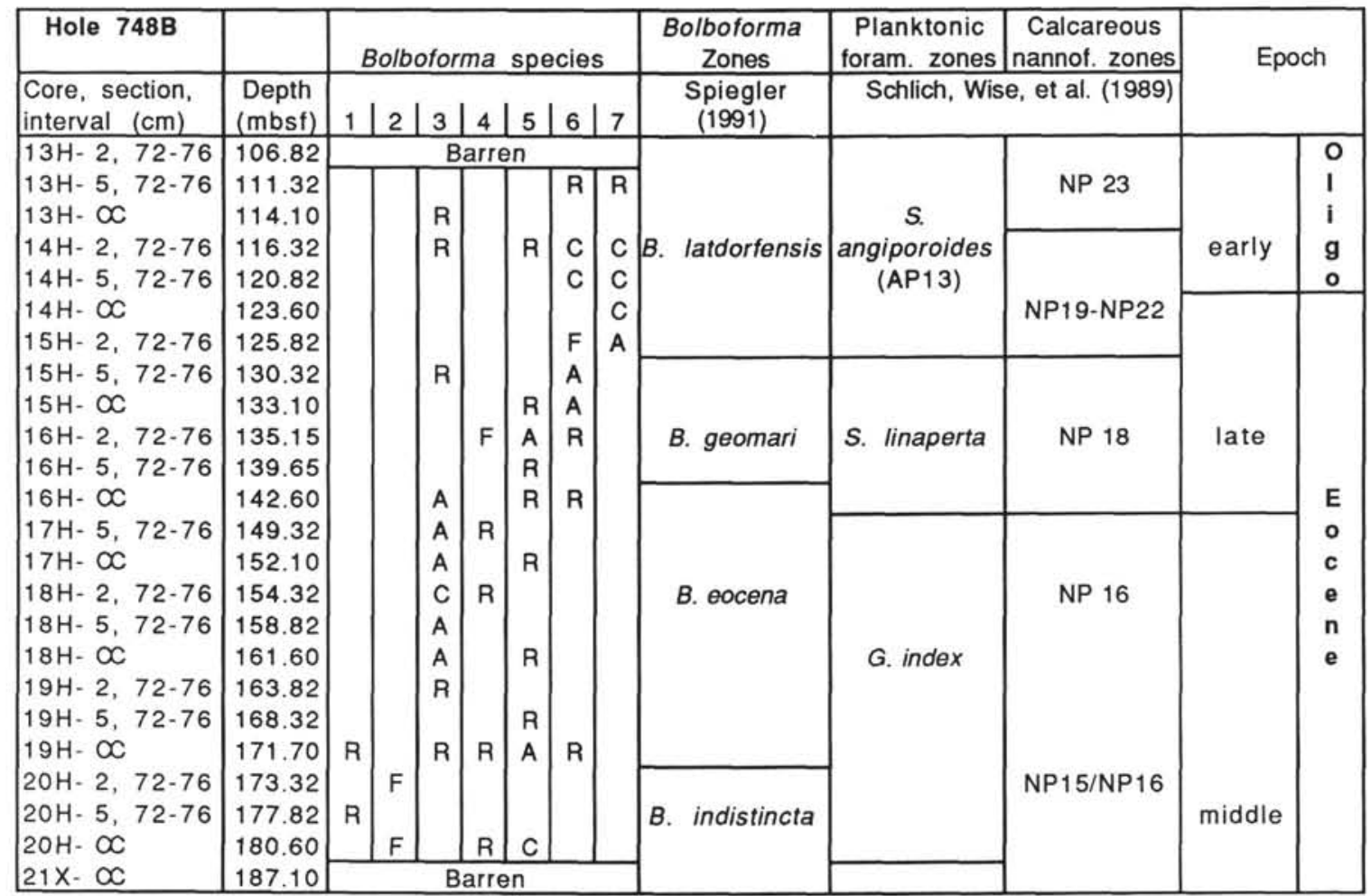

Figure 2. Stratigraphic distribution of Bolboforma in samples from Hole 748B. The correlation of proposed Bolboforma zones with planktonic foraminifer and calcareous nannofossil zones is indicated. The frequency estimation refers to a maximum number of about 100 specimens counted when the fraction $>125 \mu \mathrm{m}$ of a $20-\mathrm{cm}^{3}$ sample is spread on a counting tray. Rare $(R)=<3$ specimens; few $(F)=3-15$ specimens; common $(C)=15-30$ specimens; and abundant $(A)=>30$ specimens. $1=$ B. indistincta Spiegler and von Daniels, $1991 ; 2=$ Bolboforma sp. 1 (this study); $3=$ B. antarctica Kennett and Kennett, 1990; 4 = Bolboforma sp. B. Spiegler and von Daniels, 1991; $5=$ B. geomari Spiegler and von Daniels, 1991; $6=$ B. lamari Mackensen and Spiegler, 1989; and $7=$ B. latdorfensis Spiegler and von Daniels, 1991.

1989), which in turn were preliminarily calibrated to a geomagnetic polarity time scale (Berggren et al., 1985a, 1985b; Aubry et al., 1988). All age determinations and the positions of hiatuses are based on shipboard stratigraphy; thus, the ranges given are approximate ones.

\section{OCCURRENCE AND STRATIGRAPHIC DISTRIBUTION}

\section{Paleogene}

Although an extended Neogene sedimentary sequence was recovered at Site 748, no Bolboforma were found in sediments younger than the lower Oligocene. In Hole 748B, Bolboforma were found from Samples 120-748B-20H-CC (180.60 mbsf) through $-13 \mathrm{H}-5,72-76 \mathrm{~cm}$ (111.32 mbsf) (Fig. 2). This sediment sequence corresponds to a time span of about 13 m.y. from the middle middle Eocene through the lower Oligocene (Fig. 2), that is, from approximately $47.0 \mathrm{Ma}$ (the first appearance datum of Globigerapsis index) to 34.0 Ma (Schlich, Wise, et al., 1989).

In Hole 749B, Bolboforma were not as common as at Site 748. In many samples only a few specimens were found. Different species occurred from Samples 120-749B-10X-1, $72-76 \mathrm{~cm}$ ( $82.52 \mathrm{mbsf})$, through $-2 \mathrm{H}-5,72-76 \mathrm{~cm}$ (12.52 mbsf) (Fig. 3). This corresponds to a time span of about 15 m.y. from the middle middle Eocene through the lower Oligocene, that is, from approximately 46.5 to $31.8 \mathrm{Ma}$ (Schlich, Wise, et al., 1989).
In Hole $750 \mathrm{~A}$, a typical middle Eocene Bolboforma fauna dominated by B. antarctica was found in Sample 120-750A1R-CC (7.90 mbsf).

Four Bolboforma zones as defined in Spiegler (1991) were recognized in the Paleogene of Sites 748 and 749 (Figs. 2 and $3)$ :

1. The nominate species of the Bolboforma indistincta Zone is found at Site 748 in Samples 120-748B-20H-5, 72-76 $\mathrm{cm}$, and $-19 \mathrm{H}-\mathrm{CC}$. The upper boundary of this partial range zone is below the first occurrence (FO) of $B$. antarctica, (i.e., between Samples 120-748B-20H-2, 72-76 cm, and -19H-CC [between 173.32 and $171.70 \mathrm{mbsf}$ ]). This corresponds to an age of approximately $44.5 \pm 1.5 \mathrm{Ma}$. At Site 749 , no $B$. indistincta were found, but the FO of B. antarctica is in Sample 120749B-7X-CC. Therefore, the upper boundary of the B. indistincta Zone lies between Samples 120-749B-9H-CC and $-7 \mathrm{X}-\mathrm{CC}$ (between 81.80 and $62.80 \mathrm{mbsf}$ ). This corresponds to an age of between $45.0 \pm 1.5$ and $48.0 \pm 1.5 \mathrm{Ma}$.

2. Spiegler (1991) defined the Bolboforma antarctica Zone as a total range zone. In this study, we need to redefine the upper boundary of this zone because of the scattered occurrence of the nominate species throughout the upper Eocene and lower Oligocene. Consequently, we chose the upper boundary of the $B$. antarctica Zone above the last common occurrence (LCO) of B. antarctica. In Hole 748B the upper boundary of this zone is found above Sample 120-748B$16 \mathrm{H}-\mathrm{CC}$ (142.60 mbsf) and below Sample 120-748B-16H-5, 


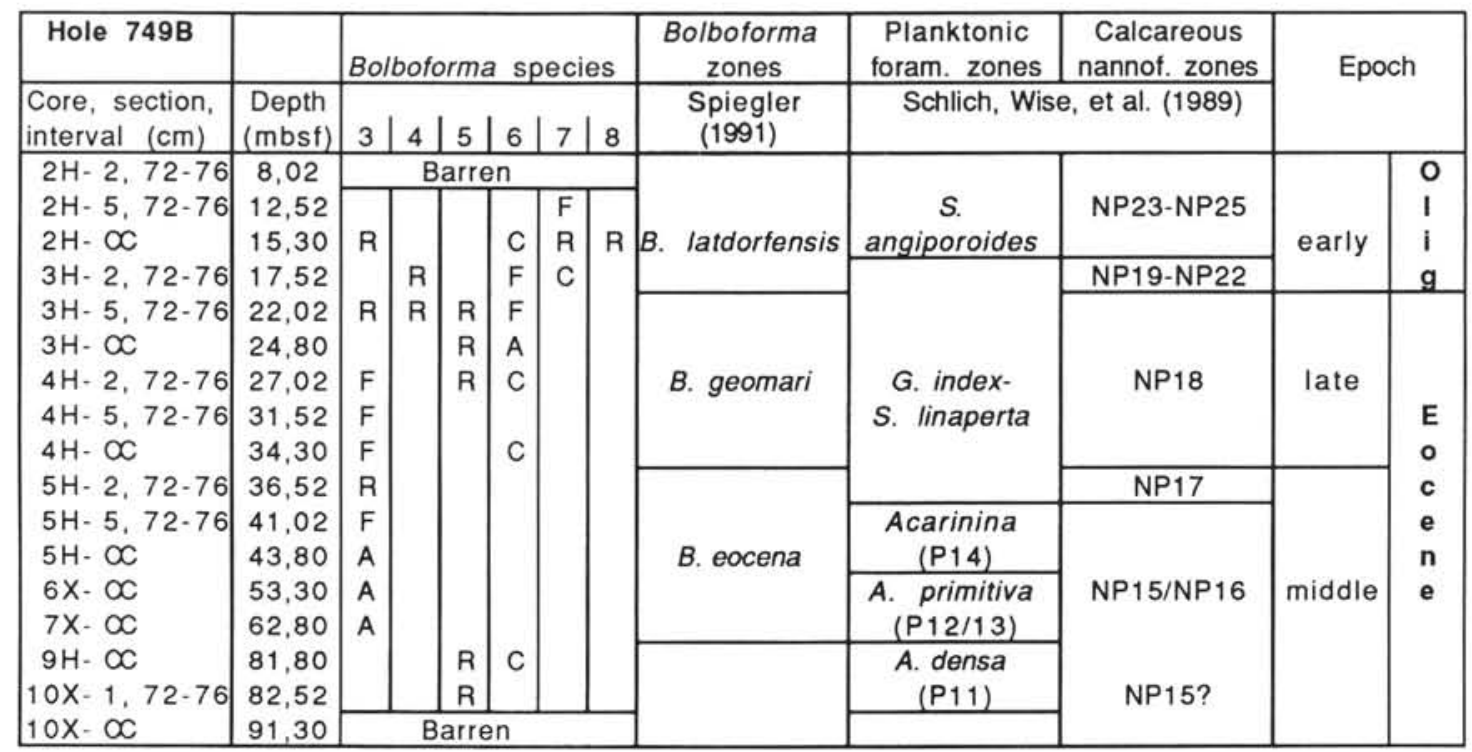

Figure 3. Stratigraphic distribution of Bolboforma in samples from Hole 749B. See Figure 2 for an explanation of terms. The correlation of proposed Bolboforma zones with planktonic foraminifer and calcareous nannofossil zones is indicated. $3=$ B. antarctica Kennett and Kennett, 1990; $4=$ Bolboforma sp. B. Spiegler and von Daniels, 1991; $5=$ B. geomari Spiegler and von Daniels, 1991; 6 = B. lamari Mackensen and Spiegler, 1989; 7 = B. latdorfensis Spiegler and von Daniels, 1991; and $8=B$. spinosa von Daniels and Spiegler, 1974.

$72-76 \mathrm{~cm}$ (139.65 mbsf). This corresponds to an age of approximately $40.0 \mathrm{Ma}$. At Site 749 the top of the $B$. antarctica Zone is between Samples 120-749B-5H-2, 73-76 cm (36.52 mbsf) and $-4 \mathrm{H}-\mathrm{CC}(34.30 \mathrm{mbsf})$ and corresponds to an age of approximately $41.5 \pm 1 \mathrm{Ma}$. According to the shipboard stratigraphy, there may be a hiatus between 34.30 and 43.80 mbsf corresponding to a time interval from 42.3 to $38.9 \mathrm{Ma}$ (Schlich, Wise, et al., 1989, "Site 749"' chapter).

3. Based on the ODP Leg 114 material, the Bolboforma geomari Zone of Spiegler (1991) was defined between the last occurrence (LO) of $B$. antarctica and the LOs of B. geomari and $B$. lamari. In this study we redefine the lower boundary of the $B$. geomari Zone just above the last common occurrence (LCO) of $B$. antarctica and the upper boundary below the FO of B. latdorfensis. At Site 748 the top of the B. geomari Zone is found between Samples 120-748B-15H-5, 72-76 cm (130.32 mbsf), and $-15 \mathrm{H}-2,72-76 \mathrm{~cm}$ (125.82 mbsf), and corresponds to an age from $<37.3$ to $>35.9 \mathrm{Ma}$. At Site 749 this boundary is situated between Samples 120-749B-3H-5, 72-76 cm (22.02 mbsf), and $-3 \mathrm{H}-2,72-76 \mathrm{~cm}$ (17.52 mbsf), corresponding to an age of approximately $37.7 \mathrm{Ma}$.

4. The youngest Paleogene Bolboforma Zone, the B. latdorfensis Zone, was defined by Spiegler (1991) between just below the FO of the nominate species and somewhere in the upper lower or upper Oligocene where the occurrence of Bolboforma spp. is extremely rare or the sediments are barren of Bolboforma. At Sites 748 and 749, this zone includes Samples 120$748 \mathrm{~B}-15 \mathrm{H}-2,72-76 \mathrm{~cm}$, through $-13 \mathrm{H}-5,72-76 \mathrm{~cm}$ (125.82 to $111.32 \mathrm{mbsf}$ ), and Samples 120-749B-3H-2, 72-76 cm, through $-2 \mathrm{H}-5,72-76 \mathrm{~cm}$ (17.52 to $12.52 \mathrm{mbsf})$, respectively.

\section{Neogene}

Neogene sediments of Hole 747A contain Bolboforma from Samples $120-747 \mathrm{~A}-7 \mathrm{H}-4,72-76 \mathrm{~cm}$ (61.72 mbsf), through $-4 \mathrm{H}-2,0-4 \mathrm{~cm}$ (29.50 mbsf). This corresponds to a time span of about $8 \mathrm{~m} . \mathrm{y}$. from the late middle Miocene through the early Pliocene, that is, from 12.5 to $\approx 3.9 \mathrm{Ma}$ (Schlich, Wise, et al., 1989).
Although a densely spaced set of Miocene samples from Hole $751 \mathrm{~A}$ was investigated, Bolboforma were found in only three samples, with only about three specimens each, randomly distributed in time between late early and early late Miocene: Samples 120-751A-8H-6, 36-40 cm (69.56 mbsf); -11H-4, 72-76 cm ( $95.42 \mathrm{mbsf})$; and $-14 \mathrm{H}-2,36-40 \mathrm{~cm}$ (120.56 mbsf).

Three of seven Bolboforma zones established by Qvale and Spiegler (1989) in the Norwegian Sea were recognized in the Neogene of Hole 747A (Fig. 4):

1. The nominate species of the $B$. compressispinosa Zone is abundant in Sample 120-747A-7H-4, 72-76 cm (61.72 mbsf), and occurs rarely in Sample 120-747A-6H-4, 72-76 cm (52.22 mbsf). Qvale and Spiegler (1989) defined the base of this zone with the LO of B. reticulata. As this species is not present in our material, we preliminarily chose the FO of the nominate species $B$. compressispinosa as the base of the zone. Similarly, the top of this zone was defined under the abundant occurrence of $B$. fragori (Qvale and Spiegler, 1989). It is difficult to differentiate between $B$. fragori, $B$. subfragori, and an additional phenotypic variation $B$. cf. subfragori, which was found in this study in significantly younger sediments; thus, we decided to chose the LCO of $B$. compressispinosa as the top of this zone. This corresponds to an age of $\approx 11.5 \mathrm{Ma}$ (Schlich, Wise, et al., 1989, "Site 747 " chapter, p. 122).

2. In the Norwegian Sea, the B. metzmacheri Zone was established as a total range zone. At Site 747, B. metzmacheri is found from Samples $120-747 \mathrm{~A}-4 \mathrm{H}-7,72-76 \mathrm{~cm}(37.72$ mbsf), through $-4 \mathrm{H}-6,36-40 \mathrm{~cm}$ (35.86 mbsf), interrupted by one barren sample at 37.36 mbsf. This sequence corresponds to the middle late Miocene from $\approx 8.0 \mathrm{Ma}$ at its base to $5.4 \pm$ $0.4 \mathrm{Ma}$ at its top (Schlich, Wise, et al., 1989, "Site 747" chapter). More detailed investigation based on diatom stratigraphy (Harwood and Maruyama, written comm., 1990) revealed several hiatuses in the upper Miocene and Pliocene; as a result a much shorter time span from $\approx 7.5$ to $6.9 \mathrm{Ma}$ (or from $\approx 7.5$ to $\approx 5.5 \mathrm{Ma}$ ) is calculated to correspond to the sedimentary sequence between 38 and 35 mbsf. 


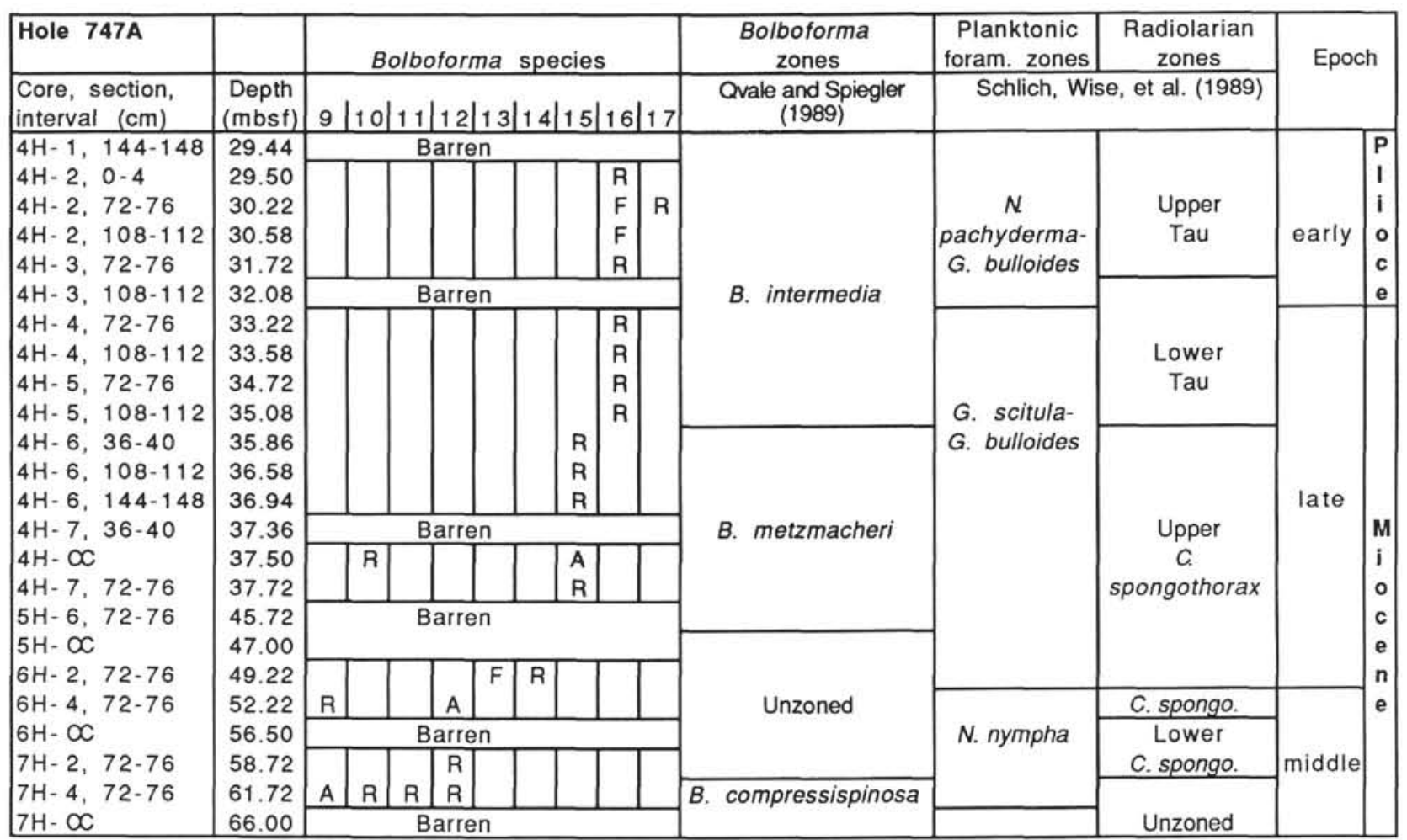

Figure 4. Stratigraphic distribution of Bolboforma in samples from Hole 747A. See Figure 2 for an explanation of terms. The correlation of proposed Bolboforma zones with planktonic foraminifer and radiolarian zones is indicated. $9=B$. compressispinosa Spiegler and von Daniels, $1991 ; 10=B$. laevis von Daniels and Spiegler, 1974; $11=$ B. pentaspinosa Spiegler and von Daniels, $1991 ; 12=B$. subfragori Spiegler and von Daniels, 1991; $13=$ B. capsula Spiegler, 1987; $14=$ B. clodiusi von Daniels and Spiegler, $1991 ; 15=$ B. metzmacheri (Clodius, 1922); $16=B$. cf. subfragori; and $17=B$. intermedia von Daniels and Spiegler, 1974.

3. According to the zonal scheme of Qvale and Spiegler (1989), the next younger zone above the $B$. metzmacheri Zone is the $B$. intermedia Interval Zone, with a defined base above the LO of $B$. metzmacheri. Consequently, this zone includes Samples 120-747A-4H-5, 108-112 cm (35.08 mbsf), through $-4 \mathrm{H}-2,0-4 \mathrm{~cm}$ ( $29.50 \mathrm{mbsf})$, only interrupted by one sample barren of Bolboforma at 32.08 mbsf. If there is no hiatus at the Miocene/Pliocene boundary (compare controversial documentation in Schlich, Wise, et al., 1989, "Site 747" chapter), the beginning of this zone corresponds to $5.4 \pm 0.4 \mathrm{Ma}$, and it ranges into the early Pliocene.

\section{DISCUSSION AND CONCLUSIONS}

\section{Paleogene}

The zonation of the middle Paleogene by Spiegler (1991) based on Leg 114 material from the southern Atlantic Ocean was found to be applicable on two Leg 120 Kerguelen sites (748 and 749). Spiegler (1991) tied her zonation to the geomagnetic polarity record, whenever possible. She calculated an age of approximately $44.5 \mathrm{Ma}$ for the base of the $B$. indistincta Zone. According to the shipboard stratigraphy, this base is at approximately $46.5 \mathrm{Ma}$ on the Kerguelen Plateau. In the southern Atlantic, the age of the base of the $B$. antarctica Zone was given at approximately $43.0 \mathrm{Ma}$ (B. eocena Zone in Spiegler, 1991). Our study indicates an age of about $45.0 \mathrm{Ma}$. This agrees well with the appearance of $B$. antarctica at $\approx 44.5$ $\mathrm{Ma}$ in the Weddell Sea (Kennett and Kennett, 1990). The age of the base of the B. geomari Zone is given by Spiegler (1991) between 39.2 and $38.1 \mathrm{Ma}$. Our data corroborate this datum and indicate an age of $\approx 39 \mathrm{Ma}$. Similarly, in the southern Atlantic, the base of the B. latdorfensis Zone is dated at approximately $36.0 \mathrm{Ma}$; at the Kerguelen Plateau this boundary is between 35.9 and $37.3 \mathrm{Ma}$.

In summary, the age estimates of the lower boundaries of the two middle Eocene Bolboforma zones based on southern Atlantic material are 1-2 m.y. younger than those derived from the Kerguelen Plateau and the eastern Weddell Sea samples. The southern Atlantic age estimates for the two late Eocene and early Oligocene zones are confirmed by the southern Indian Ocean material.

\section{Neogene}

The zonation for the middle Miocene through early Pliocene proposed by Qvale and Spiegler (1989), based on Leg 104 material from the Norwegian Sea, was only of limited use for a detailed stratigraphic subdivision of the middle to late Miocene and the early Pliocene at the Kerguelen Plateau in the southern Indian Ocean. According to Leg 120 shipboard stratigraphy, the $B$. compressispinosa Zone is found in sediments older than $\approx 11.5 \mathrm{Ma}$, which is in contrast to the stratigraphic occurrence in the Norwegian Sea, where Qvale and Spiegler (1989) defined this zone as late Miocene. Therefore, we refrained from further application of the Norwegian Sea zonation to ages near the middle/late Miocene boundary (Fig. 4). The Kerguelen Plateau range of the nominate species of the B. metzmacheri Zone from $\approx 7.5$ to $\approx 5.5 \mathrm{Ma}$ agrees well with the range given by Qvale and Spiegler (1989) as being from 7.4 Ma to somewhere between 5.89 and 5.4 Ma. In summary, the zonation of the middle and late Miocene from the Norwegian Sea may be applicable to the southern Indian Ocean material, but more work is needed to erect a Neogene southern high-latitude scheme and correlate this with the zonation from the Northern Hemisphere. 
Even though the boundary definitions of Bolboforma zones are somewhat preliminary because of the still limited knowledge of the distribution of Bolboforma in space and time, and the different species concepts used by different authors, one main conclusion is justifiable: Bolboforma biostratigraphy seems to become a useful complementary tool for the stratigraphic subdivision of sequences at the Eocene/Oligocene boundary of southern high latitudes.

\section{ACKNOWLEDGMENTS}

We thank the master and crew of the JOIDES Resolution and the ODP technical staff for their work and assistance on board ship. We also thank M. Heyn and A. Wolf for technical assistance. The constructive reviews by D. M. Kennett and J. W. Murray helped to improve the manuscript. Financial support was provided by the Deutsche Forschungsgemeinschaft to A. Mackensen, and the Bundesministerium für Forschung und Technologie to D. Spiegler (MFG 00762). This is Alfred Wegener Institute Contribution No. 344.

\section{REFERENCES}

Aubry, M.-P., Berggren, W. A., Kent, D. V., Flynn, J. J., Klitgord, K. D., Obradovich, J. D., and Prothero, D. R., 1988. Paleogene geochronology: an integrated approach. Paleoceanography, 3:707-742.

Barker, P. F., Kennett, J. P., and Scientific Party, 1988. Weddell Sea paleoceanography: preliminary results of ODP Leg 113. Palaeogeogr., Palaeoclimatol., Palaeoecol., 67:75-102.

Barrett, P. J. (Ed.), 1989. Antarctic Cenozoic History from the CIROS-1 Drillhole, McMurdo Sound. DSIR Bull., No. 245.

Berggren, W. A., Kent, D. V., and Flynn, J. J., 1985a. Jurassic to Paleogene: Part 2, Paleogene geochronology and chronostratigraphy. In Snelling, N. J. (Ed.), The Chronology of the Geological Record. Geol. Soc. London Mem., 10:141-195.

Berggren, W. A., Kent, D. V., and Van Couvering, J. A., 1985b. The Neogene: Part 2, Neogene geochronology and chronostratigraphy. In Snelling, N. J. (Ed.), The Chronology of the Geological Record. Geol. Soc. London Mem., 10:211-260.

Ciesielski, P. F., Ledbetter, M. T. , and Ellwood, B. B., 1982. The development of Antarctic glaciation and the Neogene paleoenvironment of the Maurice Ewing Bank. Mar. Geol., 46:1-51.

Douglas, R. G., and Woodruff, F., 1981. Deep-sea benthic foraminifera. In Emiliani, C. (Ed.), The Oceanic Lithosphere (Vol. 7): The Sea: New York (Wiley-Interscience), 1233-1327.

Echols, D. J., 1985. "Bolboforma": a Miocene algae(?) of possible biostratigraphic and paleoclimatic value. In Bougault, H., Cande, S. C., et al., Init. Repts. DSDP, 82: Washington (U.S. Govt. Printing Office), 605-610.

Ehrmann, W. U., 1991. Implications of sediment composition on the Southern Kerguelen Plateau for paleoclimate and depositional environment. In Barron, J., Larsen, B., et al., Proc. ODP, Sci. Results, 119: College Station, TX (Ocean Drilling Program), 185-210.

Gazdzicki, A., 1989. Microfossil Bolboforma (Chrysophyta) from Tertiary glacio-marine sediments of King George Island, West Antarctica. Polish Polar Res., 10(4):581-586.

Hambrey, M. J., Ehrmann, W. U., and Larsen, B., 1991. Cenozoic glacial record of the Prydz Bay continental shelf, East Antarctica. In Barron, J., Larsen, B., et al., Proc. ODP, Sci. Results, 119: College Station, TX (Ocean Drilling Program), 77-132.

Hambrey, M., Larsen, B., Ehrmann, W. U., and ODP Leg 119 Shipboard Scientific Party, 1989. Forty million years of Antarctic glacial history yielded by Leg 119 of the Ocean Drilling Program. Polar Rec., 25 (153):99-106.

Kennett, D. M., and Kennett, J. P., 1990. Bolboforma Daniels and Spiegler, from Eocene and lower Oligocene sediments, Maud Rise, Antarctica. In Barker, P. F., Kennett, J. P., et al., Proc. ODP, Sci. Results, 113: College Station, TX (Ocean Drilling Program), 667-673.

Mackensen, A., and Spiegler, D., 1989. A new Bolboforma (Algae, Chrysophyceae?) from the late Eocene of the southern Indian Ocean, Ocean Drilling Program Leg 120. In Schlich, R., Wise, S. W., Jr., et al., Proc. ODP, Init. Repts., 120: College Station, TX (Ocean Drilling Program), 71-72.
McNeil, D. H., 1988. New occurrence of the algal cyst(?) Bolboforma badenensis Szczechura in the Miocene of the Beaufort Sea, Arctic Canada. Micropaleontology, 34:90-96.

Mercer, J. H., 1983. Cenozoic glaciations in the Southern Hemisphere. Annu. Rev. Earth Planet. Sci., 11:99-132.

Miller, K. G., Fairbanks, R. G., and Mountain, G. S., 1987. Tertiary oxygen isotope synthesis, sea level history, and continental margin erosion. Paleoceanography, 2(1):1-19.

Müller, C., Spiegler, D., and Pastouret, L., 1984. The genus Bolboforma Daniels and Spiegler in the Oligocene and Miocene sediments of the North Atlantic and northern Europe. In Graciansky, P. C., de, Poag, C. W., Init. Repts. DSDP, 80, Pt. 1: Washington (U.S. Govt. Printing Office), 669-675.

Murray, J. W., 1979. Cenozoic biostratigraphy and paleoecology of Sites 403 to 406 based on the foraminifers. In Montadert, L., Roberts, D. G., et al., Init. Repts. DSDP, 48: Washington (U.S. Govt. Printing Office), 415-430.

1984. Biostratigraphic value of Bolboforma. Leg 81, Rockall Plateau. In Roberts, D. G., Schnitker, D., et al., Init. Repts. DSDP, 81: Washington (U.S. Govt. Printing Office), 535-539.

1987. Bolboforma from North Atlantic sites, Deep Sea Drilling Project Leg 94. In Ruddiman, W. F., Kidd, R. B., et al., Init. Repts. DSDP, 94, Pt. 2: Washington (U.S. Govt. Printing Office), 813-814.

Pallant, A., and Kaminski, M., 1989. Bolboforma from Leg 105, Labrador Sea and Baffin Bay, and the chronostratigraphy of Bolboforma in the North Atlantic. In Srivastava, S. P., Arthur, M. A., et al., Proc. ODP, Sci. Results, 105: College Station, TX (Ocean Drilling Program), 381-385.

Poag, C. W., and Karowe, A. L., 1986. Stratigraphic potential of Bolboforma significantly increased by new finds in the North Atlantic and South Pacific. Palaios, 1(2):162-171. 1987. Bolboforma (Chrysophyta?) from the western North Atlantic. In Poag, C. W., Watts, A. B., et al., Init. Repts. DSDP, 95: Washington (U.S. Govt. Printing Office), 429-438.

Qvale, G., and Spiegler, D., 1989. The stratigraphic significance of Bolboforma (Algae, Chrysophyta) in Leg 104 samples from the Vøring Plateau. In Eldholm, O., Thiede, J., Taylor, E., et al., Proc. ODP, Sci. Results, 104: College Station, TX (Ocean Drilling Program), 487-495.

Rögl, F., and Hochuli, P., 1976. The occurrence of Bolboforma, a probable algal cyst, in the Antarctic Miocene of DSDP Leg 35. In Hollister, C. D., Craddock, C., et al., Init. Repts. DSDP, 35: Washington (U.S. Govt. Printing Office), 713-719.

Savin, S. M., 1977. The history of the Earth's surface temperature during the past 100 million years. Annu. Rev. Earth Planet. Sci., 5:319-355.

Schlich, R., Wise, S. W., Jr., et al., 1989. Proc. ODP, Init. Repts., 120: College Station, TX (Ocean Drilling Program)

Shackleton, N. J., and Kennett, J. P., 1975. Paleotemperature history of the Cenozoic and the initiation of Antarctic glaciation: oxygen and carbon isotope analyses in DSDP Sites 277, 279, and 281. In Kennett, J. P., Houtz, R. E., et al., Init. Repts. DSDP, 29: Washington (U.S. Govt. Printing Office), 743-755.

Spiegler, D., 1987. Encapsulated Bolboforma (Algae, Chrysophyta) from upper Miocene deposits in the North Atlantic. Meded. Werkgr. Tert. Kwart. Geol., 24(1-2):157-166. 1991. The occurrence of Bolboforma (Algae, Chrysophyta) in the Subantarctic Paleogene of ODP Leg 114. In Ciesielski, P., Kristoffersen, Y., et al., Proc. ODP, Sci. Results, 114: College Station, TX (Ocean Drilling Program), 325-334.

Spiegler, D., and von Daniels, C. H., 1991. A stratigraphic and taxonomic atlas of Bolboforma (Protophytes, incertae sedis, Tertiary). J. Foraminiferal Res., Vol. 21.

Tappan, H., 1980. The Paleobiology of Plant Protists: San Francisco (W. H. Freeman).

Tjalsma, R. C., and Lohmann, G. P., 1983. Paleocene-Eocene bathyal and abyssal benthic foraminifera from the Atlantic Ocean. Micropaleontol., Spec. Publ., 4:1-90.

von Daniels, C. H., and Spiegler, D., 1974. Bolboforma n. gen. (Protozoa?)-eine neue stratigraphisch wichtige Gattung aus dem Oligozän/Miozän Nordwestdeutschlands. Paläontol. Z., 48:57-76.

Date of initial receipt: 5 March 1990

Date of acceptance: 20 September 1990

Ms 120B-166 


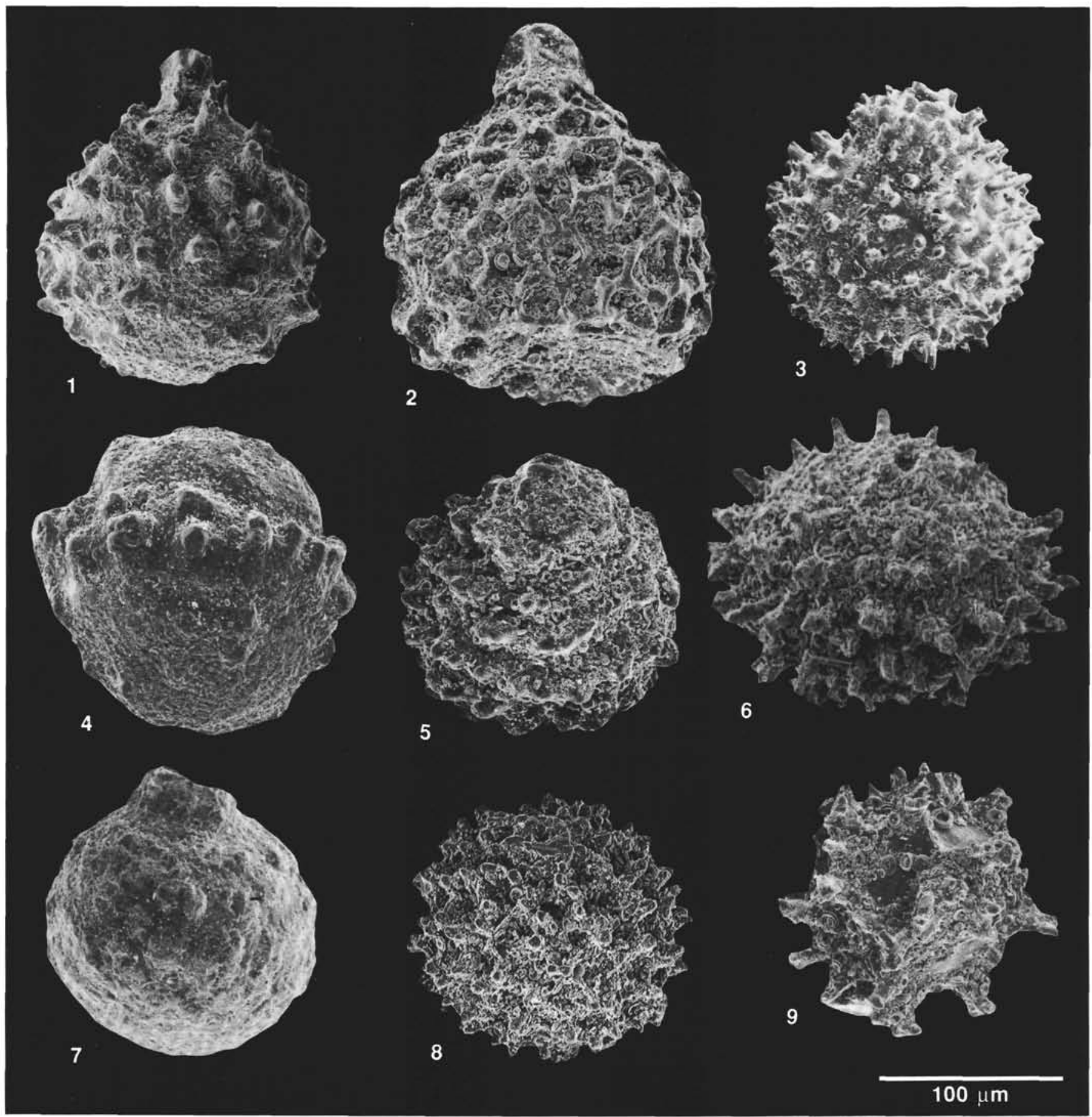

Plate 1. 1. Bolboforma cf. subfragori (transition to B. clodiusi), Sample 120-747-4H-4, 108-112 cm. 2. Bolboforma metzmacheri (Clodius, 1922), Sample 120-747-4H-7, 72-76 cm. 3. Bolboforma clodiusi von Daniels and Spiegler, 1974, Sample 120-747A-4H-7, 72-76 cm. 4. Bolboforma capsula Spiegler, 1987, Sample 120-747A-6H-2, 72-76 cm. 5. Bolboforma subfragori Spiegler and von Daniels, 1991, Sample 120-747A-6H-2, $72-76 \mathrm{~cm}$. 6. Bolboforma compressispinosa Spiegler and von Daniels, 1991, Sample 120-751A-11H-4, 72-76 cm. 7. Bolboforma laevis von Daniels and Spiegler, 1974, Sample 120-747A-7H-4, 72-76 cm. 8. Bolboforma spinosa von Daniels and Spiegler, 1974, Sample 120-751A-14H-2, $36-40 \mathrm{~cm}$. 9. Bolboforma latdorfensis, Spiegler and von Daniels, 1991, Sample 120-748B-14H-5, 72-76 cm. 


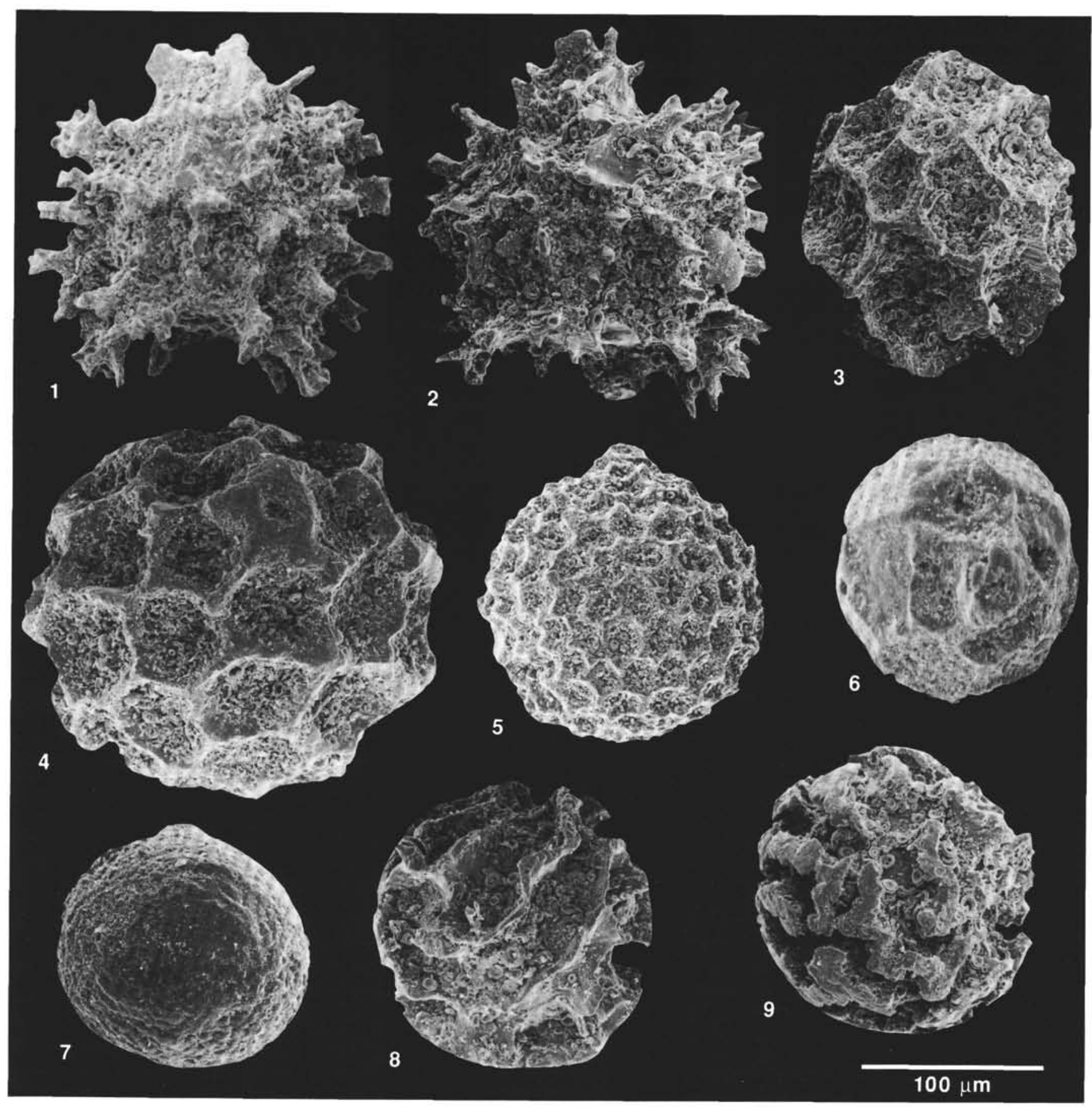

Plate 2. 1-2. Bolboforma lamari Mackensen and Spiegler 1989; (1) Sample 120-748B-15H-5, 72-76 cm; (2) Sample 120-749B-3H-2, 72-76 cm. 3-4. Bolboforma geomari, Spiegler and von Daniels, 1991; (3) Sample 120-748B-16H-2, 72-76 cm; (4) $120-748 \mathrm{~B}-20 \mathrm{H}-5$, 72-76 cm. 5. Bolboforma antarctica, Kennett and Kennett, 1990, Sample 120-749B-5H-5, 72-76 cm. 6. Bolboforma indistincta, Spiegler and von Daniels, 1991, Sample 120-749B-3H-5, $72-76$ cm. 7. Bolboforma sp. B, Spiegler and von Daniels, 1991, Sample 120-749B-3H-5, 72-76 cm. 8-9. Bolboforma sp. 1, Sample 120-748B-20H-2, 72-76 cm. 